\title{
Strategies Used by Teachers in Instilling Religious Values in Elementary School Students
}

Jepri Wulandari ${ }^{1}$ \& Rais Aqmaril ${ }^{2}$

${ }^{* 1}$ Muhammadiyah University of Surakarta, Surakarta, Indonesia

${ }^{2}$ Istanbul University, Istanbul, Turkey

*Email \& Phone: a510160179@ums.ac.id; +6281298096531

\begin{tabular}{ll}
\hline Submitted: $2021-09-12$ & DOI: $\underline{\text { https://doi.org/10.53088/eej.v1i1.148 }}$ \\
Accepted: $2021-10-17$ & \\
Published: $2021-12-20$ &
\end{tabular}

\begin{tabular}{ll}
\hline Keywords: & Abstract \\
\hline Teacher & $\begin{array}{l}\text { Background: This study aims to reveal the strategies used by teachers in instilling } \\
\text { religious values in SD Karanganyar district and reveal what are the obstacles } \\
\text { experienced by teachers in instilling religious values in SD Karanganyar district. }\end{array}$ \\
Internalization, & $\begin{array}{l}\text { The research subjects in this study are; principals, religious teachers, students, } \\
\text { and guardians of students. }\end{array}$ \\
Religious & Method: Data collection techniques used are observation, interviews, and \\
values, & $\begin{array}{l}\text { documentation. Data validation using source triangulation. The data analysis } \\
\text { technique uses source triangulation. Data analysis techniques use data }\end{array}$ \\
Elementary & $\begin{array}{l}\text { Resultion, presentation of data, and concluding. } \\
\text { School Students study results indicate that the strategies used by teachers in } \\
\text { instilling religious values include: (1) Familiarizing students with religious } \\
\text { activities every day. (2) Provide good examples/examples for students. (3) } \\
\text { Accompanying students in carrying out religious values. (4) Controlling student } \\
\text { activities, controlling student worship activities by checking control books or } \\
\text { mutabaah books owned by students. (5) Give awards to students who want to } \\
\text { carry out a program of activities to inculcate religious values. (6) sanctions for } \\
\text { students who violate or do not want to carry out the program for inculcating } \\
\text { religious values. At the same time, the obstacles experienced by teachers in } \\
\text { instilling religious values in students are (1) Lack of facilities and infrastructure } \\
\text { to support the implementation of the program for inculcating religious values. } \\
\text { (2) diverse student characteristics. (3) Substitute teachers who have not } \\
\text { mastered the reading. (4) parents who do not supervise their children's activities } \\
\text { at home. }\end{array}$ \\
\end{tabular}

\section{INTRODUCTION}

Today's developments and changes in society continue to follow the changing times. The educational setting creates children who excel in academic achievement, but the character must also be considered. Education and character building are essential things in a person's life because a character is one of the determinants of success (Utami \& Sari, 2014). 
The quality of human resources can be improved through education. Education can be done with a conscious and planned effort to create a learning atmosphere and a pleasant learning process. Students can actively develop their potential to have religious-spiritual strength, self-control, personality, intelligence, noble character, and the skills needed by themselves, society, nation. And the state (Wati \& Arif, 2017:60).

In the education system, teachers have become people who play an essential role in Indonesian education. Because the key to student success is the teacher. The teacher is the first person responsible for guiding, teaching, and training students in schools. The level of teacher preparation can be interpreted as the willingness of teachers to participate in education, teaching, guidance, training, evaluation, and assessment of students. In order to achieve educational goals, a teacher is required to be able to manage the class, use teaching methods, teaching strategies, develop teaching materials well, and improve students' abilities (Abdullah, 2017:139).

There are several types of teaching strategies in education: expository strategies, cooperative learning, inquiry, contextual teaching and learning, and problem-based learning. All strategies do not fit all materials. It depends on the context. Maybe one strategy is suitable for one particular topic but not necessarily suitable for another topic, so the teacher must have the ability to choose the best one (Fajriah, 2017:205)

Strategies in learning can make a learning process active. Teaching and learning activities are interrelated systems. The system consists of components such as teachers, students, and facilities. Each component has its role in the teaching and learning process. The teacher has compiled the RPP, and the teacher must prepare tricks so that the teacher can create efficient and effective teaching and learning activities. The trick is called Audina's teaching strategy (2020:58). The choice of strategy needs to consider the objectives, assessment, and teaching materials (Mulyadi \& Ermawati, 2014:162)

Because education and character have a very close relationship. Religious activities need to be instilled in children from an early age because the low morale almost brings destruction. As stated (Zerillo, 2012:1), ethical and moral values are fundamental to be instilled in all individuals, starting from an early age and being easily influenced. The culture of corruption, abuse of authority, dishonesty of students, disrespectful behavior to teachers, and often violating the rules and regulations in the school environment are clear evidence of the low morale in someone in this country. Kurniawan (2018:33) explains that primary education instills character in students, namely at an early age and elementary school. In essence, good morals have existed since humans were born, but to maintain these morals, habituation is needed that is carried out continuously. Therefore, character formation starts from the family, school, and community (Siwi \& Sari, 2019:2). The lack of a solid religious education causes a decline in student morality. Family, environment, and school are factors causing the lack of religious solid education for children. In addition to the lack of religious education for children, another factor is the lack of character education from an early age. Environment and schools are some factors causing the lack of religious solid education for children. In addition to the lack of religious education for children, another factor is the lack of character education from an early age. Environment and schools are some factors causing the lack of religious solid education for children. In addition to the lack of religious education for children, another factor is the lack of character education from an early age.

"Law Number 20 of (2003) concerning the National Education System, Article 3, that the purpose of national education is to develop the potential of students to become human beings who believe and fear God Almighty, have a noble character, are healthy, knowledgeable, capable, creative. , be independent, and become a democratic and responsible citizen." 
Humans are devoted to Allah and have noble character as in the basis of our country, namely the first precepts of Pancasila, which cannot be realized suddenly. It all needs a process, especially through the educational process. A person is called a strong character if they have succeeded in absorbing the values and beliefs desired by the community and practiced in their daily lives (Diah \& Oktavia, 2014: 275). Character education is national in the spirit of education. The character values contained in Pancasila include: (1) religious; (2) honest; (3) tolerant; (4) discipline; (5) work hard; (6) creative; (7) independent; (8) democratic; (9) curiosity; (10) national spirit; (11) love the homeland; (12) rewarding achievements; (13) communicative; (14) peace-loving; (15) likes to read; (16) care about the environment; (17) social problems; and (18) in charge (President of the Republic of Indonesia, 2017). One of his guidance strengthens character by providing Islamic religious education (Anwar et al., 2018:68).

\section{METHOD}

This research adopts a qualitative method and adopts a case study qualitative research type. This research was conducted in many elementary schools in the Karanganyar area, especially SD Negeri 01 Kemuning, SD Muhammadiyah Plus Malang and SD IT Al Hikmah Kemuning. Researchers went directly to the field, aiming to get accurate research data. Qualitative data is the data used in this study. Research data was collected in the form of observation data and interview recordings. Meanwhile, school principals, ustadz, guardians, students, and documents in the form of photos of religious values planting activities are the sources of data in this study.

The validity of the data in this study using triangulation. Sugiyono (2017: 372) explained that triangulation is one way to get accurate information by using various methods so that the information can be trusted so that researchers do not make wrong decisions. This study uses technical triangulation and source triangulation to check the validity of the data. The data analysis technique used in this research is the qualitative data analysis technique. Miles and Huberman (1992:16) stated, "the stages of activities in analyzing qualitative data are data reduction, data presentation and concluding/verification"

\section{RESULTS}

Based on research conducted using interview and documentation methods at SD IT AIHikmah, SD Negeri 01 Kemuning, and SD Muhammadiyah Plus Malangjiwan, researchers found data on the strategies used by teachers in instilling religious values in students. The following are the results of research showing::

\section{Strategies Used by Teachers in Instilling Religious Values}

\section{Value And Trust}

In the research that has been done, it is stated that the informants already understand religious values. Value is a person's good attitude that reflects his obedience to the religion he adheres to, which can guide someone to do something.

"Religion is a person's obedient or obedient attitude towards the religion he adheres to, which is based on love and humility towards the creator (Allah)." (AB)

"Religious values are attitudes of behavior that reflect a person's obedience in carrying out the teachings of his religion and tolerance for followers of other religions."(TS) 
All means, efforts, and plans will be carried out by teachers as implementers of education in schools to instill religious values in students. In this study, teachers commonly apply several values to instill religious values in students, namely knowing basic faith/tawhid, worship like prayer, and good manners and good habits.

"Here, children are accustomed to knowing basic faith/tawhid, worship like prayer, and good manners." (AB)

"To increase the religious value of these students, we teach good habits, good behavior, about such manners."(AK)

In the three schools that were used as research sites in this study, all applied habituation strategies in instilling religious values in their students and used theory and periodic control.

"Get used to it every day. For example, the Duha prayer." (I)

"Instilling faith by being introduced to nature, that everything Allah is the creator. With a simple concept of faith, if worship uses theory and practice, examples, and periodic control, the point is that worship is a habit that must always be controlled, including that adab is also formed because of repeated habits.

$(A B)$

The method used by the teacher to find out the extent to which children understand what has been said about religious values is by observing the attitudes of children to behave in their daily lives and controlling all children's religious activities in the control book that has been given to each child.

"By observing children's behavior at school."(M)

"Judging from his daily behavior. So when they have carried out the habituation at school, it means that students have understood what we are teaching."(AK)

"In terms of material evaluation, each chapter has a competency test, quarterly and semester exams. For amaliyah, children are given a mutabaah book/control book. This is checked monthly by the teacher." (AB)

\section{Programs In School}

To support the inculcation of students' religious values in elementary schools, of course, there are several programs implemented in schools. There are several programs implemented to instill religious values in children, including praying in congregation, reading the Qur'an, tahfidz, muroja'ah, and implementing daily prayers.

"The program is character, etiquette, worship, and tahfidz. In worship, we emphasize prayer, and it is always controlled. Habituation of prayer in congregation at school, Duha prayer etc. For the upper class, there is mabit." (AB) 
"For the program, there are several, miss, including: memorizing short letters, BTQ, praying Duha in congregation, praying Duhur in congregation, praying to start and close the lesson." (TS)

"There are many worship activities, apart from shaking hands, we also have worship services such as praying Duha, continue tahfidz." (AC)

The programs implemented in schools such as congregational prayers, reading the Qur'an, and muroja'ah have been implemented since the school was founded.

"Yes, since this school existed." (MA) "Since the school was founded." (AB)

Students are very happy and quite enthusiastic in carrying out the habituation applied in this school.

"Students are very happy."(M)

"Alhamdulillah, the students are quite enthusiastic."(MA)

\section{Religious Language Mastery}

Language is something that is quite important in instilling religious values in children. Because with language we can communicate. In this study, the teacher uses language that is easily understood by children, for example by using everyday language and mixed language.

"Explained using everyday language with an example in real life."(I)

"Delivered in a language that is easily accepted by students, for example using a mixed language."(TS)

The way to introduce it is quite diverse, namely by teaching reading iqro', learning the hijaiyah letters, and imitating what the teacher does. This activity is not only carried out during hours outside of learning, but there are also some that are integrated into learning.

"By introducing. By learning to read iqro' as well as by writing. Anyway, the child here must be able to recite the Koran. Because many of our religious teachings are in the Qur'an. So the children must be able to recite the Koran. There are also Arabic lessons here. (AC)

"Introduction to hijaiyah letters." (M)

"Usually the teacher gives examples, students imitate and repeat, or by imitating direct objects, sticking vocabulary on walls and related objects, etc." (AB) 
In doing the things above, students are also very enthusiastic and quite active in accepting what has been conveyed by the teacher.

"Students are very enthusiastic and interested in receiving activity material and interact well during the activity."(TS)

"Students are quite active."(MA)

These religious activities in their daily life are not only made with material, but are made in various ways such as reading, memorizing, made with songs, students are shown videos, and practice of course so that students do not feel bored.

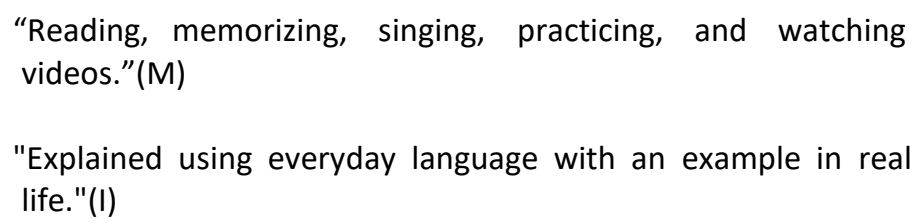

There are various ways to know that students understand what the teacher is teaching, such as through tests and observing student behavior.

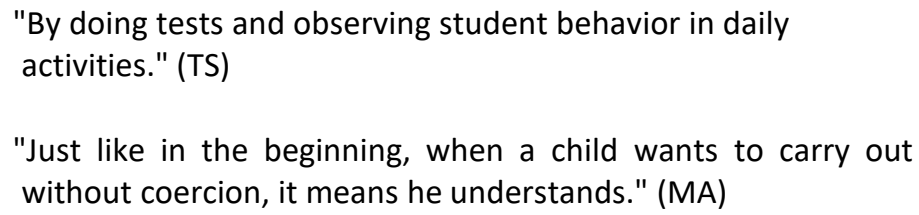

\section{Religious Practice}

Activities that exist in the school environment in order to implement religious values in the three Karanganyar district elementary schools which are used as research sites are carried out every day as a habituation program in schools. For the activities on the schedule. For example, at SD IT Al-Hikmah Kemuning, muroja'ah activities are carried out every morning before learning hours start, prayer activities in the morning until break time.

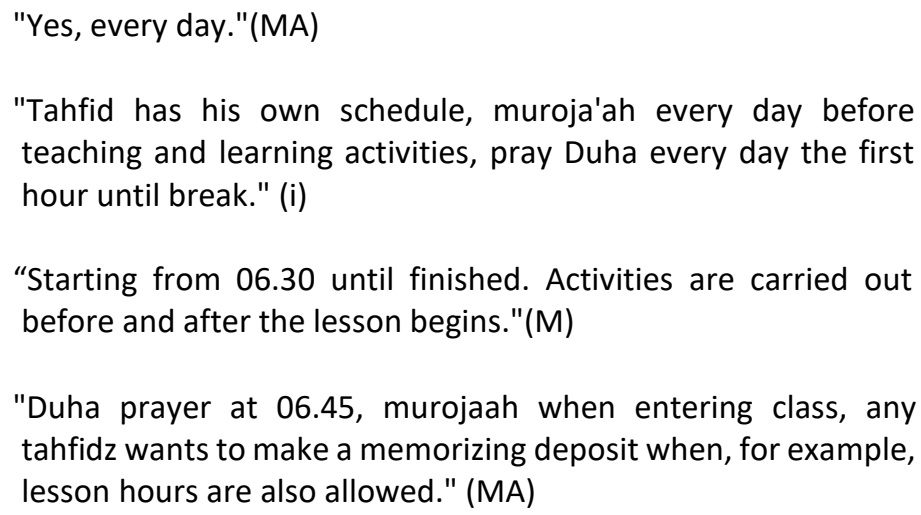

The implementation of activities in this school is not only aimed at students, but this activity is also attended by all school members. Like a teacher, because the teacher here is tasked with providing examples to students and guiding activities. 


\begin{abstract}
"Yes" (MA)
"Teachers also participate in these activities because they guide students and set an example for students." (TS)
\end{abstract}

The teacher gives appreciation to students who are willing to behave well and carry out activities implemented at school. The appreciation given to students is very diverse, such as praise, stars, grades and prizes. so that children are enthusiastic about worshiping in the context of inculcating religious values, parents also give appreciation to their sons / daughters.
"Awards are given according to the type of activity carried out and are not always in the form of an item, it can be with praise and value."(TS)
"Give me pocket money, take them for walks, get stories from me, and compliments." $(\mathrm{J})$
"The stars that will later be used for additional value, or if they have been collected, can be replaced with chocolate so that the children are happy."(I)

Sanctions are given to students who violate or commit inappropriate actions. Penalties/sanctions are given according to what has been violated by the students, and the punishment given is educational. Examples of punishments given to students are memorizing in front of the class, cleanliness such as sweeping the classroom and pulling grass, going home late, and activities that are not carried out, such as not praying Duha at that time and being told to pray Duha. Of course the punishment given to students is educational.

"They were told to memorize, clean, and go home last."(AB)

"Because it is related to worship, all punishments are educational in nature, such as students being asked to carry out activities that were not previously done, memorizing letters or sometimes pulling grass."(MA)

Sanctions or punishments are given to students who do not want to carry out or violate the program of activities. For example, by asking students to memorize letters or students to carry out activities that they do not want to carry out, and giving them advice. But there are also those who do not give punishment to their children because they feel that their children have carried out these activities in an orderly manner.

"Students are not punished, but are advised to carry out these activities." (M)

"Every time students don't want to do it."(MA) 
"The punishment is given to every student who does not want to do activities. For example, by asking students to memorize letters or students to carry out activities that they do not want to carry out." (TS)

"Alhamdulillah I have never been punished, thank God my children are obedient and obedient."(J)

\section{Group Life}

Activities in the school are carried out by all school members, such as teachers, students, and staff at the school.

"All school members (principals, teachers, staff/employees and students)." (TS)

"All school community"(I)

The implementation of the inculcation of religious values in schools is of course accompanied by class teachers, religious teachers, and accompanying teachers who are listed in the schedule.

“Class teacher and assistant teacher."(I)

"On the schedule, between the class teacher and the religion teacher." $(A B)$

The target of this activity is students. The rest are teachers, because the teachers at the school are the role models for the students. Therefore, teachers are also included as targets in the implementation of this program.

"All school residents."(TS)

"Of course students, the rest are teachers." (MA)

"Everything, because the teacher is also a human being at school, he must be enthusiastic and must set an example for the children."(I)

This activity that can be carried out in this school cannot be separated from the efforts of someone who wants to make his school more advanced by making his students have noble character, good manners, and obedience to worship. In elementary schools, which are used as research sites, the activities are initiated by school principals, teachers, and foundations.

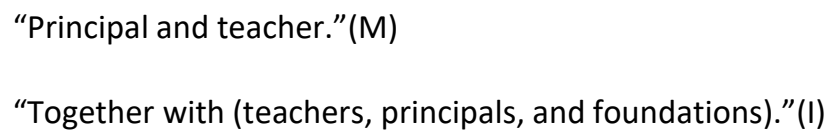

In every activity, of course, there is one person who is in charge of the activity, so that the activity runs smoothly and in accordance with what is desired. The school principal is in charge of these three schools. 
"Headmaster, if it's a teacher every day."(I)

“Headmaster."(M)

\section{Barriers Experienced by Teachers in Instilling Religious Values}

The following are some of the factors that hinder the inculcation of religious values in Karanganyar district elementary schools.

\section{Facilities and infrastructure}

The existing facilities and infrastructure are quite complete, such as a prayer room, books, iqro' and prayer equipment. However, there are still schools that have incomplete facilities and infrastructure for inculcating religious values. For example, at SD Muhammadiyah Plus, Malangjiwan, which does not yet have a mosque/mushola at school, which requires halls and classrooms to be used as places of worship.

"If it supports $100 \%$ of course not yet. Because the school is still in the stage of cleaning up. We just pray we still use the hall and the classroom."(MA)

"Mushola, places for ablution, iqro', al-Qur'an prayer mats, mukena, religious books, etc."(M)

\section{Student}

The diverse characteristics of students make teachers find it difficult to guide students to want to carry out religious values planting activities.

"Students become an inhibiting factor when they are unwilling or not enthusiastic in carrying out activities optimally because students are one of the targets of the activity program." (TS)

"When you don't want to carry out activities at school." (MA)

Public

The busyness of the community is one of the inhibiting factors for the implementation of the program for inculcating religious values because sometimes people are indifferent to the programs in schools. Parents do not control the activities of their children.

"Parents do not control their children's activities at home. Not all parents are aware of that."(MA)

"The community becomes one of the inhibiting factors when they do not condition students to participate in the program at school and do not care about the school program."(TS)

Based on the data and findings obtained, the researcher concludes that:

\section{DISCUSSION}

In terms of language, religious value comes from a combination of two words, namely the word value and the word religion. The value of the word can be explained from etymology and terminology. From an etymological point of view, value is price and degree. 
The measure of effort and purpose for choosing certain actions or activities is called value. But it should be emphasized that value is an empirical quality which is sometimes difficult or cannot be defined (Rifa, 2016:118).

Based on the results of the study, it is known that the informants already understand the value of religion. This value is a person's good attitude, which reflects his persistence in religion, and can be a guide for someone to do something.

Religious education for students in schools is a school effort to shape student morality. As executor of school education, teachers will instill religious values in students through various means, efforts and planning. In this study, teachers usually use several values to instill religious values in students. These values are knowing basic faith/tawhid, BTQ, worship like prayer, good manners, and habituation of polite behavior. The values of life that reflect the growth and development of religious life are religious values which consist of three main elements of aqidah, worship and morals, which become behavioral guidelines following religious rules in achieving safety and welfare, and happiness in life in this world and the hereafter (Umro, 2018:154)

An essential factor in character education is the habit factor. From the expert's point of view, the character is consistent with morality. Morals can be formed by habituation and growing awareness within the individual, even though students are forced and refuse to do a good deed or character. However, after a long practice, they are continuously accustomed to it, and by understanding the importance of the worship they do, they will become a good character that is imprinted in them (Zaitun \& Habiba, 2013).

\section{CONCLUSION}

The strategies used by teachers in instilling religious values in elementary school students in Karanganyar Regency, which are used as research sites, include: (1) By getting students to do religious activities every day. (2) Remind students to carry out religious activities. (3) Provide good examples/examples for students. (4) Accompanying students in carrying out religious values. (5) Controlling student activities by checking control books or mutabaah books owned by students. (6) Give awards for students who want to carry out program activities and provide sanctions for students who violate.

As for the obstacles teachers face in instilling religious values, namely: (1), The lack of existing facilities and infrastructure supports the program's implementation for inculcating religious values. (2) Characteristics of diverse students. (3) Substitute teachers who have not mastered the reading. (4) Parents who do not supervise their children's activities at home.

\section{Implication}

Based on the study of the theoretical framework of thinking and the results of the research, the implications related to the strategies used by teachers in instilling religious values in students in the Karanganyar district were made as research sites were obtained. Both practical and theoretical implications

The results of this study can be used as a reference for teachers in elementary schools in instilling religious values in students so that students can have noble character and noble character. The strategy used by teachers at the Karanganyar district elementary school is to make repeated habits, which is according to Pavlov's theory.

\section{REFERENCE}

Abdullah, G. (2017). Elementary School Teachers' Readiness in The Implementation of FullDay School Program in Gorontalo Regency. 118, 138-144. https://www.atlantispress.com/proceedings/icset-17/25886522 
Anwar, C., Saregar, A., Hasanah, U., \& Widayanti, W. (2018). The Effectiveness of Islamic Religious Education in the Universities: The Effects on the Students' Characters in the Era of Industry 4.0. Tadris: Jurnal Keguruan Dan Ilmu Tarbiyah, 3(1), 77. https://doi.org/10.24042/tadris.v3i1.2162

Audina, Y., Zega, N., Simarmata, A., Situmeang, K. V., \& Tarigan, S. N. (2020). An Analysis of Teacher's Strategies in Teaching Reading Comprehension. Jurnal Pendidikan, 11(1), 94-105.

https://ejournal.poltektegal.ac.id/index.php/siklus/article/view/298\%0Ahttp://repo sitorio.unan.edu.ni/2986/1/5624.pdf\%0Ahttp://dx.doi.org/10.1016/i.jana.2015.10.0 05\%0Ahttp://www.biomedcentral.com/14712458/12/58\%0Ahttp://ovidsp.ovid.com/ovidweb.cgi?T=JS\&P

Utami, R.D.., \& Sari, A. O. (2014). Peningkatan Minat Dan Hasil Belajar Ipa Melalui Strategi Word Square Pada Siswa Kelas V Di Sd Negeri 03 Jetis Kecamatan Jaten Kabupaten Karanganyar Tahun Ajaran 2013/2014. 57-62. https://journals.ums.ac.id/index.php/ppd/article/view/945

Fajriah, F. (2017). Learning Journal: Improving Teaching Strategies Through Students' Reflections. Sukma: Jurnal Pendidikan, 1(2), 301-327. https://doi.org/10.32533/01204.2017

Indonesia, P. R. (2003). Undang-undang Republik Indonesia nomor 20 tahun 2003 tentang sistem pendidikan nasional. Jakarta: Pemerintah Republik Indonesia.

Kurniawan, S. (2018). Pendidikan Karakter: Konsepsi Dan Implementasinya secara terpadu Dilingkungan Keluarga, sekolah, Perguruan Tinggi. http://library.fip.uny.ac.id/opac/index.php?p=show detail\&id=7418

Miles, M. B., \& Huberman, A. M. (1992). Analisis data kualitatif. Jakarta: UI press.

Mulyadi, S. K., \& Ermawati, S. (2014). Peningkatan Hasil Belajar Matematika Pada Soal Cerita Melalui Strategi Think Talk Write ( Ttw ) Siswa Kelas V Sd Negeri 02 Gemantar. Profesi $\begin{array}{lll}\text { Pendidikan Dasar, 1(2), 162-17. } & \text { 162 }\end{array}$ http://journals.ums.ac.id/index.php/ppd/article/view/1005/682

Rifa, M. K. (2016). Internalisasi Nilai-Nilai Religius Berbasis Multikultural 10 Dalam Membentuk Insan Kamil. Jurnal Pendidikan Agama Islam, 4(1), 116-133. https://doi.org/10.15642/jpai.2016.4.1.116-133

Siwi, D. A., \& Sari, N. K. (2019). Role of Teachers Class as A Motivator and Guidance Students in Education of Discipline Character Through Movement of School Literation According to Nawacita in Elementary School of Gabus 01 Pati 2017/2018 Academic Year. International Journal of Multicultural and Multireligious Understanding, 6(1), 1. https://doi.org/10.18415/ijmmu.v6i1.459

Sugiyono, P. D. (2017). Metode Penelitian Pendidikan: Pendekatan Kuantitatif, Kualitatif, R\&D (Cetakan Ke). Bandung: CV Alfabeta.

Umro, J. (2018). Penanaman Nilai-Nilai Religius Disekolah Yang Berbasisi Multikultural. $\begin{array}{llll}\text { Jurnal Al } & \text { Makrifat, } & \text { 149-166. }\end{array}$ http://ejournal.kopertais4.or.id/tapalkuda/index.php/makrifat/article/view/3213

Wati, D. C., \& Arif, D. B. (2017). Penanaman nilai-nilai religius di sekolah dasar untuk penguatan jiwa profetik siswa. Konferensi Nasional Kewarganegaraan III. http://eprints.uad.ac.id/9629/

Zaitun, \& Habiba, S. (2013). Implementasi Sholat Fardhu Sebagai Sarana Pembentuk Karakter Mahasiswa Universitas Maritim Raja Ali Haji Tanjungpinang. Aklim: Jurnal
Pendidikan
Agama
Islam
11
(2):
153-168

http://jurnal.upi.edu/file/06 Implementasi Shalat Fardhu - Zaitun.pdf 